\title{
SERVICE ENTRY IN EMERGING MARKETS: INTRODUCING FOREIGN SERVICES TO RUSSIAN MARKETS
}

Ania Izabela Rynarzewska, The Florida State University, USA

\begin{abstract}
Emerging markets are those in the process of transitioning from being centrally planned to democracy driven with a more independent economy that is market-orientated. Emerging markets are currently experiencing rapid economic growth. Because of current and past economic and political situations, emerging markets also typically differ from developed markets.

The objective of this study is to propose a testable model of service entry in Russia. This paper attempts to identify areas of focus for firms considering investing in emerging markets. At the core of this framework is the assumption that consumers in emerging markets behave differently than those in developed countries. Each country experiences globalization differently. These differences are primarily due to diverse historical and cultural backgrounds, demographics, economic resources and development priorities, as well as the current and emerging political-economic trends. This is why companies need to learn about the economic and social conditions in emerging markets in order to be successful.

In summary, this paper attempts to identify a number of important variables likely influencing Russian customers to approach foreign services. Using the Theory of Planned Behavior, variables that are likely to influence Russian customer to intend to approach new service were identified and include: normative beliefs, motivation to comply, valence and strength, ability to choose and the price of service offered. Finally, a potential moderator of the intention and actual action that is the first time service encounter was also proposed. Trust in the services provider is thought to moderate this relationship. In times when Russian market becomes flooded with foreign investors, this paper offers areas of focus for the companies that wish to enter this rich in opportunity market.
\end{abstract}

References available upon request. 